\title{
A Study of HIV Knowledge and Stigma Among Health Care Workers from Istanbul-Turkey
}

\section{İstanbul-Türkiye'den Sağlık Çalışanlarında HIV Bilgisi ve Stigması Üzerine Bir Çalışma}

\author{
๑ Osman Sağsöz ${ }^{1}$ • S Sevgi Duman², • Güzin Zeren Öztürk², • Seçil Arıca ${ }^{3}$ \\ ${ }^{1}$ Kaynaşlı State Hospital, Düzce, Turkey \\ ${ }^{2}$ University of Health Sciences Turkey, Şişli Hamidiye Etfal Training and Research Hospital, Clinic of Family Medicine, İstanbul, Turkey \\ ${ }^{3}$ University of Health Sciences Turkey, Prof. Dr. Cemil Taşçığlu City Hospital, Clinic of Family Medicine, İstanbul, Turkey
}

Background: Human immunodeficiency virus (HIV) is a global public health problem affecting over 38 million people. While the yearly number of new cases is reducing in the world, this number is increasing in our country. Among the health care workers (HCW), stigma is an important obstacle. We aimed to assess the knowledge and attitudes related to HIV/AIDS among HCW.

Materials and Methods: The study included HCW actively working at University of Health Sciences Turkey Şişli Hamidiye Etfal Training and Research Hospital for one year or longer, who visited the hospitals exclusive health clinic for hospital personnel for any reason from July to October 2019 and agreed to participate in the study. Participants took an information form prepared by researchers in face-to-face interviews. The statistical program SPSS was used to analyze data.

Results: A total of 332 participants with the mean age of 28.5 years (min 21, max 60) were included. 52.4\% ( $n=174)$ successfully identified the transmission routes and the most known route was "transmission by sexual routes" and the most mistaken route was "body fluids". $17.8 \%$ responded with "I agree" to the "all HIV (+) individuals should be quarantined" statement, $20.2 \%$ agreed that "I wouldn't let my child meet with the child of an HIV (+) parent". $9.6 \%$ agreed with "HIV (+) individuals should carry an externally visible sign" and $5.4 \%$ agreed "HIV is only seen in homosexuals". Nurses and personnel had high agreement rates with the quarantine and labeling judgments. Personnel most frequently agreed with "HIV is only seen in homosexuals". When education status and Likert-type questions about stigma were compared, there were significant differences identified for all 4 questions $(p=0.000)$.

Conclusion: Inadequate information and prejudices of HCW may lead to serious results in terms of stigma for HIV (+) individuals. Providing information about problems encountered by these people and revealing the outcomes of stigma may ensure HCW to develop empathy and break the negative feedback cycle of stigma.

Keywords: HIV, HIV stigma, health care workers, HIV knowledge

Amaç: İnsan bağışıklık eksikliği virüsü (HIV) dünya üzerinde 38 milyon insanı etkileyen küresel bir halk sağlığı sorunudur. Dünya genelinde yıllık yeni olgu sayısı azalırken, ülkemizde bu sayı giderek artmaktadır. HIV ile ilgili bakım zincirinin her alanında bulunan sağlık çalışanlarında HIV stigması büyük bir problemdir. Bu nedenle çalışmamızda sağlık çalışanlarının HIV/AIDS ile ilgili bilgi ve tutumlarını değerlendirmeyi amaçladık.

Gereç ve Yöntemler: Çalışma 2019 Temmuz-Ekim ayları arasında herhangi bir nedenle Sağlık Bilimleri Üniversitesi Şişli Hamidiye Etfal Eğitim ve Araştırma Hastanesi çalışan sağlığı polikliniğine gelen ve çalışmaya katılmayı kabul eden; bir yıl ve üstünde Şişli Hamidiye Etfal Eğitim ve Araştırma Hastanesinde aktif çalışan sağlık çalışanlarına yapılmıştır. Katılımcılara tarafımızdan hazırlanan bilgi formu yüz yüze sorgulama yöntemi ile uygulanmıştır. İstatistiksel analizde SPSS programı kullanılmıştır.

Bulgular: Çalışmaya toplam 332 kişi katılmış olup; yaş ortalaması 28,5 (min: 21-maks: 60) idi. Katılımcılardan bulaş yolunu bilme açısından başarılı olanların oranı \%52,4 (n=174), en fazla bilinen doğru yol "cinsel yol ile bulaş" ve yanlış yol "vücut sıvıları” idi. \%17,8 “Tüm HIV (+) bireyler karantinaya alınmalıdır” yargısına katılmıştır. \%20,2 “Çocuğumu, ebeveyni HIV (+) olan

Address for Correspondence: Osman Sağsöz, Kaynaşlı State Hospital, Düzce, Turkey

Phone: +90 5057360341 E-mail: osmansagsoz1@gmail.com ORCID ID: orcid.org/0000-0001-6225-3888

Received: 15.02.2021 Accepted: 01.03.2021 
çocukla görüştürmem”, \%9,6 “HIV (+) bireyler dışarıdan görülebilen işaret taşımalıdır." ve \%5,4 “HIV sadece eşcinsellerde görülür” yargılarına katılmışlardır. Karantina ve işaret taşıma yargılarında hemşireler ve personeller yüksek oranda katılıyorum cevabı verirken, "HIV (+) bireyler sağlık kurumlarında çalışmamalıdır” ve "HIV (+) öğretmenin olduğu sınıfta çocuğumun eğitim almasını istemem." yargılarına doktorlar daha sık katılıyorum cevabı vermiştir. "HIV sadece eşcinsellerde görülür” yargısına ise personeller en sık katılıyorum cevabı vermiştir. Eğitim alma durumu, stigma ile ilgili Likert tipi sorularla karşılaştırıldığında, 4 soruda da anlamlı farklılık saptanmıştır ( $\mathrm{p}=0,000)$.

Sonuç: Sağlık çalışanlarının bilgi eksikliği ve önyargıları HIV (+) bireyler için stigma açısından ciddi sonuçlar doğurabilir. Verilen eğitimlerde teknik konuların yanında bu kişilerin karşılaştıkları problemleri ortaya koyan eğitimlerin verilmesi, stigmanın sonuçlarının ortaya konması sağlık çalışanlarının empati kurmasını sağlayarak; stigmanın ortaya çıkardığı kısır döngünün kırılmasına neden olabilir.

Anahtar Kelimeler: HIV, HIV stigması, sağlık çalışanları, HIV bilgisi

\section{Introduction}

Human immunodeficiency virus (HIV) is a global public health problem affecting over 38 million people around the world. Since the first HIV case was observed in Turkey in 1985 , there have been 25,809 HIV (+) people reported to be positive with confirmed tests and 1985 AIDS cases (1). While the yearly number of new cases is reducing in the world in general, this number is increasing in our country (2). A study in 2019 observed that half of the people with HIV infection were late to seek medical help (3).

One of the reasons for this delay is the fear of stigmatization due to HIV. Stigma related to HIV can be defined as negative attitudes and beliefs about people living with HIV (PLWH) and a process of devaluation $(4,5)$. Stigma related to HIV may be expressed through a variety of routes. It may be categorized as stigma expected to be experienced when the HIV status is known, perceived stigma related to how people living with HIV should behave, internalized stigma, shame, experienced stigma and discrimination (6). Due to the fear created by stigmatization, individuals may delay getting tested for HIV (7), and experience difficulty in disclosing their seropositive status to those around them, beginning and continuing treatment and seeking medical care when they require $(8,9,10)$. The fight against stigma and fear related to HIV have become a part of the fight against HIV. Health care workers have a big role in this fight. For this reason, in our study, we aimed to assess the knowledge and attitudes related to HIV/AIDS among health care workers.

\section{Material and Methods}

The study included health care workers (doctors, nurses and other personnel) actively working at University of Health Sciences Turkey Şişli Hamidiye Etfal Traning and Research Hospital for one year or longer, who visited the Şişli Hamidiye
Etfal Training and Research Hospital exclusive health clinic for hospital personnel for any reason from July to October 2019 and agreed to participate in the study. Verbal consent was obtained from the participants. Participants took an information form prepared by the researchers in face-toface interviews. During this period, the number of personnel working in the hospital was 2.432, with sample size calculated as 332 for $95 \%$ confidence interval.

Our study received permission from University of Health Sciences Turkey Şişli Hamidiye Etfal Training and Research Hospital ethics committee, dated 25.06.2019 and numbered 2452.

\section{Information Form}

The information form prepared by the researchers after literature screening included questions about the participants' sociodemographic information in addition to questions about general information related to HIV, transmission routes, and risk factors and 3-point Likert judgement statements to assess attitudes towards PLWH.

Participants were given points according to their status of knowing transmission routes and individuals at risk (Cronbach alpha: 0.632). According to a Cronbach alpha reliability study, this value is acceptable (11). Correct answers about at-risk individuals and risky situations were given 1 point, with wrong answers given 0 points and response points for total risk status was calculated for all participants. The median value was calculated as $7(\min 2, \max 8)$ for those with points above 7 accepted as successful in correctly knowing risk groups, while those with points below 7 were accepted as unsuccessful in knowing risk groups.

Correct answers to questions related to transmission routes were given 1 point, with wrong answers given 0 points and knowledge of transmission route totals were calculated for all participants. The median value was 12 (min 5, max 13) with 12 points or more accepted as successfully knowing 
transmission route and less than 12 points accepted as unsuccessful.

\section{Statistical Analysis}

The statistical program SPSS was used to analyze data. Parameters in the study were classified as categoric and discrete. Numerical data were given as mean and standard deviation while categorical data were given as median and percentage. T-test was used in comparisons of numerical data while the chi-square test was used in comparisons of categorical data. Statistical analyses were completed using the SPSS software with a $p$ value of 0.05 accepted as statistically significant.

\section{Results}

The study included a total of 332 participants with the mean age of 28.5 years (min 21 , max 60). The sociodemographic features of participants are given in Table 1. The number of individuals who received education related to HIV was 234. Among participants, $84.3 \%(n=280)$ stated they had encountered PLWH at least once.

\section{Assessment of Responses to Questions About Knowledge of HIV/AIDS}

When the responses about the frequency of HIV/AIDS in Turkey were analyzed, 155 people (46.7\%) answered correctly. The majority of these people $(72.3 \%$; $n=112)$ worked in clinical units, while $79.4 \%(n=123)$ had received education. The rate of correct responses to the question about the \% probability of transmission after needlestick injuries was $41 \%$

\begin{tabular}{|l|l|}
\hline \multicolumn{2}{|l|}{ Table 1. Sociodemographic features of participants } \\
\hline Variable & $\mathbf{n}(\%)$ \\
\hline $\begin{array}{l}\text { Sex } \\
\text { Female } \\
\text { Male }\end{array}$ & $242(72.9)$ \\
& $90(27.1)$ \\
\hline $\begin{array}{l}\text { Occupation } \\
\text { Doctor } \\
\text { Nurse }\end{array}$ & $171(51.5)$ \\
Personnel & $98(29.5)$ \\
\hline $\begin{array}{l}\text { Department } \\
\text { Internal medicine }\end{array}$ & $63(19)$ \\
\hline $\begin{array}{l}\text { Surgical } \\
\text { Emergency }\end{array}$ & $230(69.3)$ \\
\hline Training related to HIV/AIDS & $71(21.4)$ \\
Received & $31(9.3)$ \\
Did not receive & \\
\hline Estimated number of PLWH known & $234(70.5)$ \\
None & $97(29.5)$ \\
\hline 1-4 & \\
5-10 & $52(15.7)$ \\
$>10$ & $128(38.5)$ \\
\hline HIV: Human immunodeficiency virus & $51(15.4)$ \\
\hline
\end{tabular}

$(n=136)$.

Responses of participants to knowledge statements in likert scale are given in Table 2, with the association with occupation evaluated. Nurses had higher rates of "I agree" in response to the question "I think I have adequate information about HIV" compared to doctors and personnel $(p=0.003)$. Doctors responded to the question "HIV (+) individuals should be checked for other infectious diseases" with "I agree" mostly $(p=0.000)$. Nurses had higher rates of "I agree" in response to the statement "I know how to approach an HIV (+) patient" $(p=0.000)$. Doctors were more likely to disagree with the false statement "there is no transmission if tests are negative in the first week after unprotected sexual relations with an HIV $(+)$ individual" $(p=0.000)$.

\section{Assessment of Knowledge of HIV/AIDS Transmission Routes and Related Factors}

The knowledge of transmission routes of participants is given in Table 3, with the most known routes of "transmission by sexual routes" and the most mistaken route of "body fluids." The number of people who correctly identified all routes was 94 (28.3\%). All participants were given a score according to their correct answers regarding transmission routes, and those who scored equal to or greater than the calculated median value were considered successful. The percentage of individuals who successfully identified the transmission routes was $52.4 \%(n=174)$, but the rate of those who were unsuccessful was $43.1 \%(n=143)$.

Table 4 shows the relationship between knowledge of HIV transmission routes and influencing factors, and correctly identifying transmission routes was found to be related to HIV education $(p=0.000)$. Doctors were the most successful group whereas other personnel were the least successful group $(p=0.000)$. When success in identifying transmission routes was compared according to department, the success rate was $35.5 \%$ for those working in the emergency service, $59.2 \%$ for those in the surgical unit, and $59.1 \%$ for those in clinics, and this was statistically significant $(p=0.041)$.

\section{Assessment of Knowledge of HIV/AIDS risk Status and Related Factors}

The participants' knowledge on risk status is given in Table 5 with the most well-known risk of "unprotected sexual relations" and least well known risk of "unprepared medical interventions." All participants were given a score according to their correct answers regarding at-risk individuals and risky situations, and those who scored equal to or greater than the calculated median value were considered successful. The percentage of successful participants in terms of identifying at-risk individuals and risky situations was $52.4 \%$ ( $n=174$ ), and 
Table 2. Responses of participants to knowledge statements

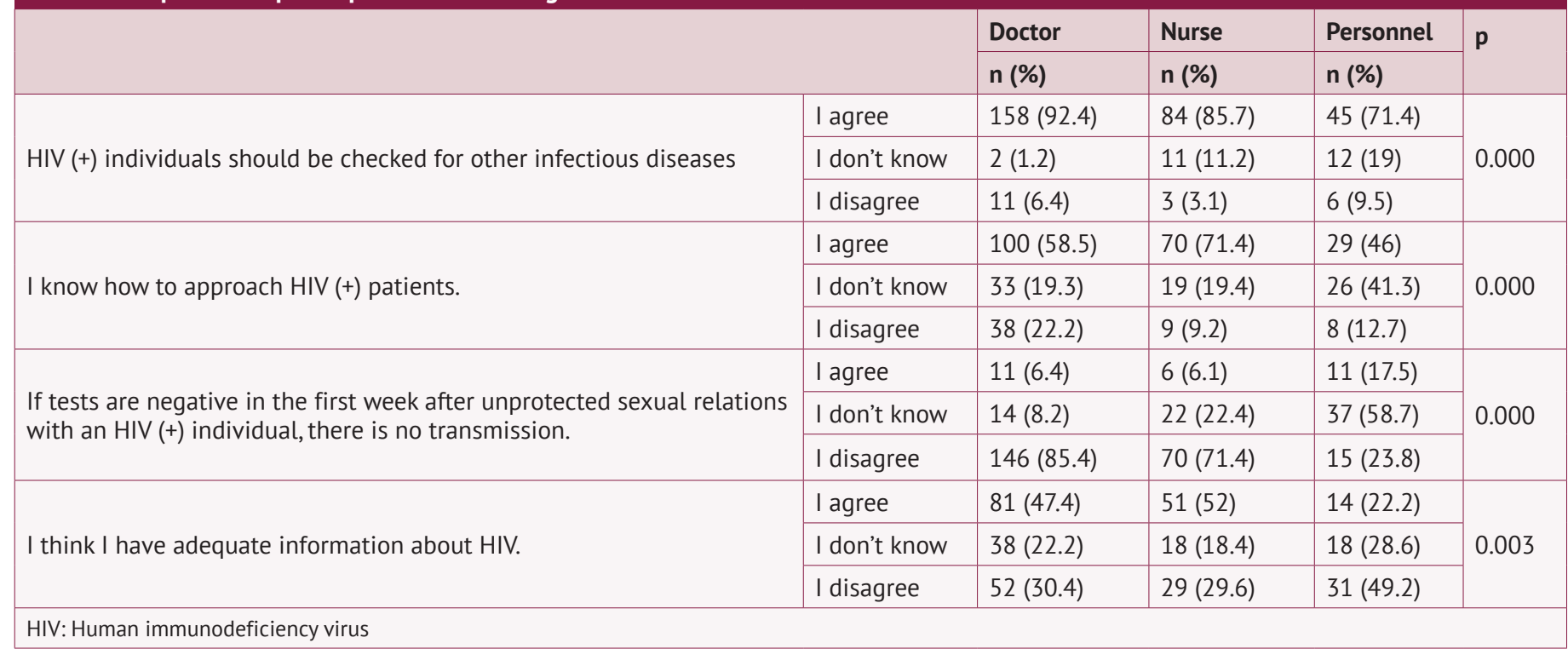

Table 3. Responses about HIV/AIDS transmission routes and data

\begin{tabular}{|l|l|l|}
\hline Transmission Routes & $\begin{array}{l}\text { \% of people } \\
\text { answering yes }\end{array}$ & $\begin{array}{l}\text { \% of people } \\
\text { answering no }\end{array}$ \\
\hline Through blood & 96.7 & 3.3 \\
\hline Intravenous drug, substance use & 74.2 & 25.8 \\
\hline Sexual relations & 98.3 & 1.7 \\
\hline Body fluids (sweat, tears) & 35 & 65 \\
\hline $\begin{array}{l}\text { Personal belongings (clothing, } \\
\text { towels) }\end{array}$ & 8.3 & 91.7 \\
\hline In air & 0.8 & 99.2 \\
\hline Skin contact (handshakes) & 2.5 & 97.5 \\
\hline Domestic items (forks, knives) & 9.2 & 90.8 \\
\hline Common use areas (pools, gyms) & 6.7 & 93.3 \\
\hline Toilets, sinks & 10 & 90 \\
\hline Insect bites & 13.3 & 86.7 \\
\hline From mother to infant during birth & 83.3 & 16.7 \\
\hline Organ transplants & 86.7 & 13.3 \\
\hline HIV: Human immunodeficiency virus & & \\
\hline
\end{tabular}

the percentage of successful participants was $47.6 \%$ ( $n=158)$. Success rate was associated with receiving HIV education.

The association between participants' knowing risk status and influencing factors is given in Table 6. There was a significant association identified with occupation. Doctors and nurses were more successful, in that order, compared to other health personnel $(p=0.000)$. Educational status and place of education were statistically significant $(p=0.000)$.

Assessment of Judgement Statements About Assessment of PLWH Attitudes: (People Living with HIV)
Among participants, $17.8 \%$ responded with "I agree" to the "all HIV (+) individuals should be quarantined" statement, $23.8 \%$ agreed that HIV (+) individuals should not work in health facilities, $24.7 \%$ agreed that "I would not like my child to receive education in a class with an HIV (+) teacher", 20.2\% agreed that "I would not let my child meet with the child of an HIV (+) parent". Of participants, $9.6 \%$ agreed with the judgement statement that "HIV (+) individuals should carry an externally visible sign' and $5.4 \%$ agreed that 'HIV is only seen in homosexuals".

The association of judgement statements to assess participant attitudes to PLWH with occupation is given in Table 7. Apart from the statements "the individual being HIV $(+)$ is an obstacle to marriage", "I would not let my child meet with the child of an HIV (+) parent" and "if my child had HIV, I would support them instead of blaming them", all judgements were identified to be associated with occupation. Nurses and personnel had high agreement rates with the quarantine and labeling judgments, while doctors responded with "I agree" more often to "HIV (+) individuals should not work in health facilities" and "I would not like my child to receive education in a class with an HIV (+) teacher" statements. Personnel most frequently agreed with the judgement that "HIV is only seen in homosexuals". When education status and Likerttype questions about stigma were compared, it was found that there were significant differences identified for all 4 questions $(p=0.000)$.

\section{Discussion}

Health care workers are professionally educated health service providers and are responsible for providing accurate 


\begin{tabular}{|c|c|c|c|c|}
\hline & & Successful & Failed & $\mathbf{p}$ \\
\hline \multirow{2}{*}{ According to sex } & Female & $59.1 \%$ & $40.9 \%$ & \multirow{2}{*}{0.193} \\
\hline & Male & $51.1 \%$ & $48.9 \%$ & \\
\hline \multirow{3}{*}{ According to department } & Emergency & $35.5 \%$ & $64.5 \%$ & \multirow{3}{*}{0.041} \\
\hline & Surgery & $59.2 \%$ & $40.8 \%$ & \\
\hline & Clinic & $59.1 \%$ & $40.9 \%$ & \\
\hline \multirow{3}{*}{ According to occupation } & Doctor & $78.9 \%$ & $21.1 \%$ & \multirow{3}{*}{0.000} \\
\hline & Nurse & $50 \%$ & $50 \%$ & \\
\hline & Personnel & $7.9 \%$ & $92.1 \%$ & \\
\hline \multirow{2}{*}{ According to training status } & Received & $66 \%$ & $34 \%$ & \multirow{2}{*}{0.000} \\
\hline & Did not receive & $35.1 \%$ & $64.9 \%$ & \\
\hline
\end{tabular}

\begin{tabular}{|l|l|l|}
\hline Table 5. Responses about risk status for HIV/AIDS \\
\hline Risk states & $\begin{array}{l}\text { \% of people } \\
\text { answering } \\
\text { yes }\end{array}$ & $\begin{array}{l}\text { \% of people } \\
\text { answering } \\
\text { no }\end{array}$ \\
\hline Being a health care worker & 88 & 12 \\
\hline Having unprotected sexual relations & 95.2 & 4.8 \\
\hline Using intravenous medication (drugs) & 88.9 & 11.1 \\
\hline $\begin{array}{l}\text { Sexual relations with an HIV + } \\
\text { individual }\end{array}$ & 83.4 & 16.6 \\
\hline Be exposed to sexual assault & 69.9 & 30.1 \\
\hline Having tuberculosis & 18.1 & 81.9 \\
\hline Travelling in risky regions & 24.1 & 75.9 \\
\hline Unprepared medical interventions & 45.8 & 54.2 \\
\hline HIV: Human immunodeficiency virus & & \\
\hline
\end{tabular}

Table 6. Correlation of participant knowledge on risky situations and influencing factors

\begin{tabular}{|l|l|l|l|l|}
\hline \multicolumn{2}{|c|}{} & Successful & Failed & p \\
\hline \multirow{2}{*}{$\begin{array}{l}\text { According to } \\
\text { sex }\end{array}$} & Female & $54.1 \%$ & $45.9 \%$ & \multirow{2}{*}{0.182} \\
\cline { 2 - 4 } & Male & $47.8 \%$ & $54.1 \%$ & \\
\hline \multirow{3}{*}{$\begin{array}{l}\text { According to } \\
\text { department }\end{array}$} & Emergency & $48.6 \%$ & $51.6 \%$ & \\
\cline { 2 - 4 } & Surgery & $53.5 \%$ & $46.5 \%$ & \multirow{2}{*}{0.887} \\
\cline { 2 - 4 } & Clinic & $52.6 \%$ & $47.4 \%$ & \\
\hline \multirow{2}{*}{$\begin{array}{l}\text { According to } \\
\text { occupation }\end{array}$} & Doctor & $59.6 \%$ & $40.4 \%$ & \\
\cline { 2 - 4 } & Nurse & $57.1 \%$ & $42.9 \%$ & \multirow{2}{*}{0.000} \\
\cline { 2 - 4 } & Personnel & $25.4 \%$ & $74.6 \%$ & \\
\hline \multirow{2}{*}{$\begin{array}{l}\text { According to } \\
\text { training status }\end{array}$} & Received & $59.1 \%$ & $40.9 \%$ & \multirow{2}{*}{0.000} \\
\cline { 2 - 4 } & Did not receive & $36.1 \%$ & $63.9 \%$ & \\
\hline
\end{tabular}

and reliable information to society about topics like diseases, preventive precautions and treatments. For this reason, inservice education in the health field is important in terms of keeping up to date.

As a result of developments in the field of HIV/AIDS, important steps have been taken in terms of early diagnosis and treatment to stop the disease for PLWH. There are studies showing that when the viral load of PLWH is at unidentifiable levels, these people are not infectious (12).

When participants were asked about transmission risk due to needlestick injuries in our study, $41 \%$ gave the correct answer. When divided according to occupation, $25 \%$ of nurses and $8 \%$ of personnel gave the correct response. Studies show that especially nurses and laboratory employees encounter contact with blood and body fluids with needlestick accidents; however, when questions about the transmission rate due to being stuck by an infected patient's needle were asked, only a very small portion gave the correct answer $(13,14)$. Studies, similarly, showed lack of information about occupational diseases and work accidents among health personnel $(15,16)$, and that adding these topics to educational meetings during working life and even informing individuals who attend routine check-ups in occupational health clinics with special booklets/brochures will be beneficial.

In a study on assistant doctors, most participants gave the correct answer when asked about the prevalence of HIV in Turkey (17). In our study, less than half of participants correctly knew the prevalence. The reason for this may be that the sample comprised of other health personnel along with doctors.

When previous studies were investigated, it was observed that health care workers had inadequate information about HIV transmission routes; inadequacies about questions related to transmission routes like saliva, sharing drinking glasses and fly bites were notable $(18,19,20)$. In our study, $56.9 \%$ successfully knew information about transmission routes, with $28.3 \%$ providing all the right answers. The most commonly mistaken transmission route was $38.9 \%$ for body fluids (sweat, tears). Among those who were unsuccessful, $25.2 \%$ were doctors $(n=36), 34.2 \%$ were nurses $(n=49)$ and 
$40.6 \%$ were other personnel $(n=58)$. It is considered that the reason for the wrong answers by clinicians may be due to their branches. In fact, those working in branches with high infection probability like surgery and emergency services had more information. While doctors and nurses had similar rates of success for correct answers about risk status, there was a significant difference for the points for transmission route knowledge. In the two groups, those who had received education were significantly more successful, which is parallel to the findings of studies before and after education in the literature $(13,18,21)$. We think training of health personnel about infectious diseases during and after faculty education will reduce this deficient information.

One of the basic factors in the stigma forming against PLWH is the thought of catching HIV infection while providing health services (6). Incorrect information about

Table 7. Correlation of judgement statements about PLWH of participants with occupation

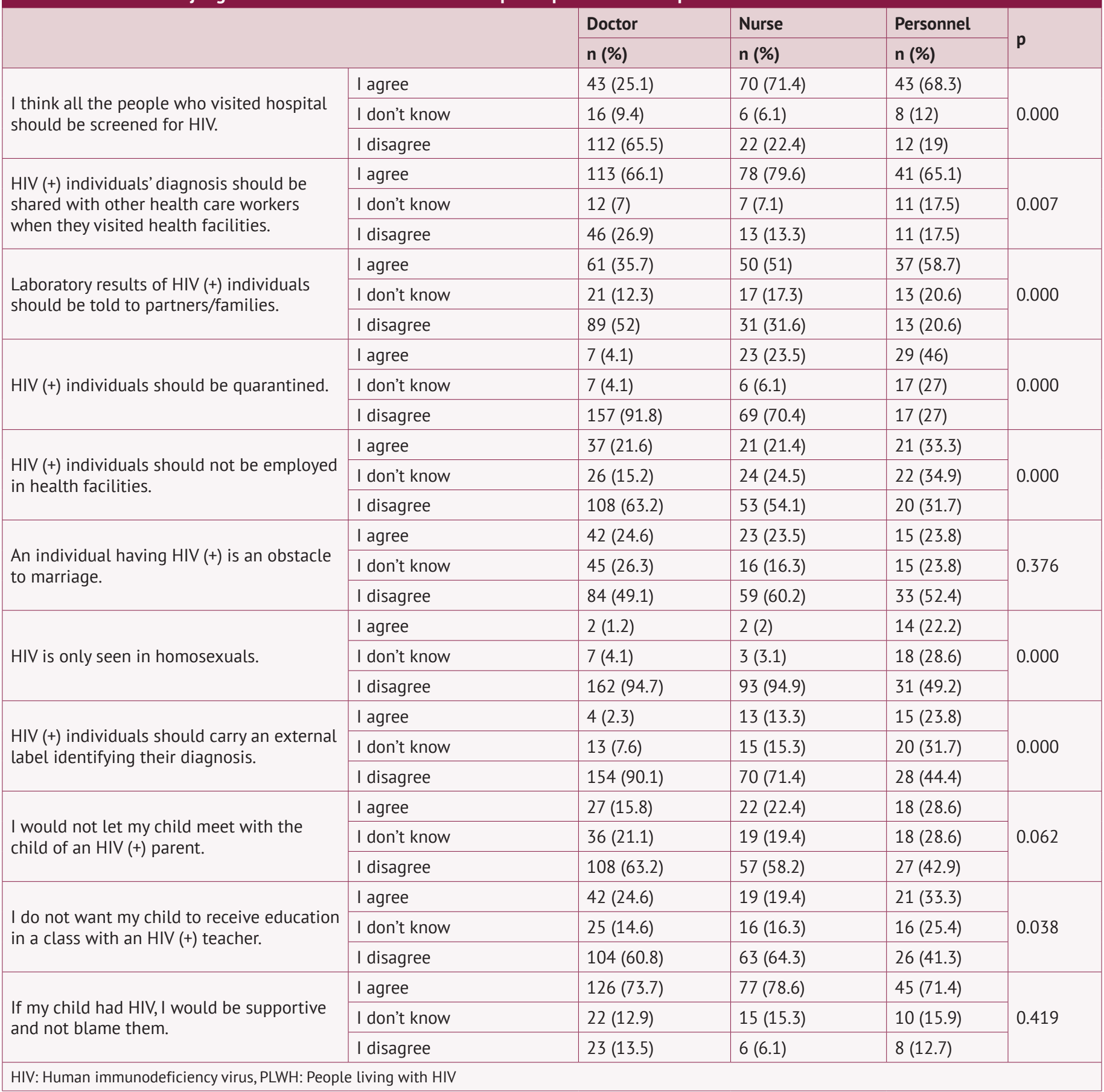


transmission routes and related rates may trigger this fear and increase the stigma. In our study, when the status of receiving education was compared with questions about stigma related to $\mathrm{PLWH}$, receiving education was found to be associated with less stigma. The increase in knowledge levels with education will reduce incorrect information about transmission routes and rates and may reduce this fear and stigma.

In our study, participants responded to statements questioning stigma like "I would not let my child meet with the child of an HIV (+) parent", "I do not want my child to receive education in a class with an HIV (+) teacher", "HIV (+) individuals should be quarantined", and "HIV (+) individuals should carry an external label identifying their diagnosis" with "I agree" at substantial rates (10-20\%). A study in India found that similar statements received similar response rates (22). These rates were similar in our study. A study in Washington in America questioning stigma among health care workers in a variety of categories obtained similar results from a scale for stigma rates, as in our study (23). A similar study in Saudi Arabia found stigma rates were again similar to our study (20). This situation shows that a significant portion of health care workers have prejudice against HIV $\left(^{+}\right)$individuals, even though they live in different areas of the world. The stigma related to HIV does not display cultural and geographical differences, though there are some small differences. In this situation, precautions should be taken against poor outcomes that may be involved for HIV (+) individuals.

In the study, the majority of responses to statements related to knowledge and stigma displayed significant differences identified between doctors, nurses and personnel, but it is notable that the 3 occupational groups had rates of agreement above $70 \%$ for the statement "if my child had HIV, I would be supportive and not blame them". This situation shows that observing HIV in our close surroundings may ensure empathy forms and prejudices are revised.

Fear of stigma is known to be a factor delaying early diagnosis and treatment of infection and as a result,spreading infection in terms of increasing transmission $(7,8,9,10)$. In addition to technical topics like treatment and surveillance about HIV/AIDS infection in trainings, providing information about problems encountered by these people and revealing the outcomes of stigma may ensure health employees to develop empathy and break the negative feedback cycle of stigma Appendix $(1,2)$.

\section{Conclusion}

Inadequate information and prejudices of health care workers, who have an important role in all areas of the care chain, related to HIV may lead to serious results in terms of stigma for HIV (+) individuals. Though this rate is low among doctors and nurses, it is high among hospital personnel. For this reason, it is essential to train all health personnel about this topic.

In addition to technical topics like treatment and surveillance about HIV/AIDS infection in trainings, providing information about problems encountered by these people and revealing the outcomes of stigma may ensure health care workers to develop empathy and break the negative feedback cycle of stigma.

\section{Ethics}

Ethics Committee Approval: Our study received permission from University of Health Sciences Turkey Şişli Hamidiye Etfal Training and Research Hospital Ethics Committee, dated 25.06.2019 and numbered 2452.

Informed Consent: Verbal consent was obtained from the participants.

Peer-review: Internally peer-reviewed.

\section{Authorship Contributions}

Concept: O.S., S.D., G.Z.Ö., S.A., Design: O.S., S.D., G.Z.Ö., S.A., Data Collection or Processing: O.S., S.D., S.A., Analysis or Interpretation: O.S., S.D., G.Z.Ö., S.A., Literature Search: O.S., S.D., S.A., Writing: O.S., S.D., G.Z.Ö.

Conflict of Interest: No conflict of interest was declared by the authors.

Financial Disclosure: The authors declared that this study received no financial support.

\section{References}

1. Halk Sağlığı Genel Müdürlüğü. HSGM HIV-AIDS istatistik; e2020 Last Accessed Date: 11.12.2020.Available from: https://hsgm.saglik.gov.tr/tr/ bulasici-hastaliklar/hiv-aids/hiv-aids-liste/hiv-aids-istatislik.html\%0A [Crossref]

2. Halk Sağlığı Genel Müdürlüğü. Türkiye HIV/AIDS kontrol programı; e2020 Last Accessed Date: 31.12.2020. Available from: https://hsgm.saglik. gov.tr/depo/birimler/Bulasici-hastaliklar-db/hastaliklar/HIV-ADS/TaniTedavi_Rehberi/HIV_AIDS_Kontrol_Programi.pdf [Crossref]

3. Karaosmanoğlu HK, Mete B, Gündüz A, Aydin ÖA, Sargin F, Sevgi DY, et al. Late presentation among patients with human immunodeficiency virus infection in Turkey. Cent Eur J Public Health. 2019;27:229-234. [Crossref]

4. Centers for Disease Control and Prevention. CDC HIV stigma and discrimination; e2020 Last Accessed Date: 31.12.2020. Available from: https://www.cdc.gov/hiv/basics/hiv-stigma/index.html [Crossref]

5. Joint United Nations Programme on HIV/AIDS. UNAIDS fact sheet stigma and discrimination; e2020 Last Accessed Date: 31.12.2020. Available from: https://data.unaids.org/publications/fact-sheets03/fs_stigma discrimination_en.pdf [Crossref]

6. Stangl AL, Lloyd JK, Brady LM, Holland CE, Baral S. A systematic review of interventions to reduce HIV-related stigma and discrimination from 2002 to 2013: how far have we come? J Int AIDS Soc. 2013;16(3 Suppl 2):18734 [Crossref] 
7. Stall R, Mills TC, Williamson J, Hart T, Greenwood G, Paul J, et al. Association of co-occurring psychosocial health problems and increased vulnerability to HIV/AIDS among urban men who have sex with men. Am J Public Health. 2003;93:939-942. [Crossref]

8. Venables E, Casteels I, Manziasi Sumbi E, Goemaere E. "Even if she's really sick at home, she will pretend that everything is fine.": Delays in seeking care and treatment for advanced HIV disease in Kinshasa, Democratic Republic of Congo. PLoS One. 2019;14:e0211619. [Crossref]

9. Kinsler JJ, Wong MD, Sayles JN, Davis C, Cunningham WE. The effect of perceived stigma from a health care provider on access to care among a low-income HIV-positive population. AIDS Patient Care STDS. 2007;21:584-592. [Crossref]

10. Katz IT, Ryu AE, Onuegbu AG, Psaros C, Weiser SD, Bangsberg DR, et al. Impact of HIV-related stigma on treatment adherence: systematic review and meta-synthesis.J Int AIDS Soc. 2013;16(3 Suppl 2):18640. [Crossref]

11. Kilic S. Cronbachs alpha reliability coefficient. J Mood Disord. 2016;6:4748. [Crossref]

12. Preventionaccess.org. Prevention access campaign consensus statement; e2020 Last Accessed Date: 3.12.2020. Available from: https://www. preventionaccess.org/consensus [Crossref]

13. He L, Lu Z, Huang J,Zhou Y, Huang J,Bi Y, et al. An integrated intervention for increasing clinical nurses' knowledge of HIV/AIDS-related occupational safety. Int J Environ Res Public Health. 2016;13:1094. [Crossref]

14. Kimaro L, Adinan J, Damian DJ, Njau B. Prevalence of occupational injuries and knowledge of availability and utilization of post exposure prophylaxis among health care workers in Singida District Council, Singida Region, Tanzania. PLoS One. 2018;13:e0201695. [Crossref]

15. Arafa AE, Mohamed AA, Anwar MM. Nurses' knowledge and practice of blood-borne pathogens and infection control measures in selected BeniSuef Hospitals Egypt. J Egypt Public Health Assoc. 2016;91:120-126. [Crossref]
16. Singh B, Paudel B, Kc S. Knowledge and practice of health care workers regarding needle stick injuries in a tertiary care center of Nepal. Kathmandu Univ Med J (KUMJ). 2015;13:230-233. [Crossref]

17. Egici M, Zeren Öztürk G, Arıca S, Bektemür G. Assessment of knowledge levels of family medicine residents about HIV/AIDS. Eur Arch Med Res. 2018;34:267-272. [Crossref]

18. Umeh CN, Essien EJ, Ezedinachi EN, Ross MW. Knowledge, beliefs and attitudes about HIV/AIDS-related issues, and the sources of knowledge among health care professionals in southern Nigeria. J R Soc Promot Health. 2008;128:233-239. [Crossref]

19. Adelekan ML, Jolayemi SO, Ndom RJ, Adegboye J, Babatunde S, TundeAyimode M, et al. Caring for people with AIDS in a Nigerian teaching hospital: staff attitudes and knowledge. AIDS Care. 1995;7(Suppl 1):S63-S72. [Crossref]

20. Memish ZA, Filemban SM, Bamgboyel A, Al Hakeem RF, Elrashied SM, AlTawfiq JA. Knowledge and attitudes of doctors toward people living with HIV/AIDS in Saudi Arabia. J Acquir Immune Defic Syndr. 2015;69:61-67. [Crossref]

21. Köse Ş, Mandıracıoğlu A, Kaptan F, Özbel Y, Mermut G. Improving knowledge and attitudes of health care providers following training on HIV/AIDS related issues: a study in an urban turkish area. Turkiye Klinikleri J Med Sci. 2012;32:94-103. [Crossref]

22. Mahendra VS, Gilborn L, Bharat S, Mudoi R, Gupta I, George B, et at. Understanding and measuring AIDS-related stigma in health care settings: a developing country perspective. SAHARA J. 2007;4:616-625. [Crossref]

23. Houston P, Powell E, Khan J, Sultana S, Kwagyan J, Kharfen M, et al. Thirtyfive years later: HIV stigma in Washington, DC health care workers.J Assoc Nurses AIDS Care. 2019;30:344-351. [Crossref] 


\section{Appendix 1. Human immunodeficiency}

\section{1-Age:}

2-Gender:

a) Female

b) Male

\section{3- Job definiton:}

a) Doctor

b) Nurse

c) Other health personnel

4- Which department are you working?....

5-Working field?

a) Inpatient clinic

b) Outpatient clinic

c) Emergency room

5- How long have you been working? ....... month/year

6-Approximately how many HIV (+) patients have you encountered?
a) None
b) $1-4$
c) $5-10$
$\mathrm{d}>10$

7- Have you ever received education about HIV/AIDS?

a) Yes

b) No

8- If yes, where?

a) University

b) After university

9- What do you think is prevalance of HIV/AIDS in Turkey?
a) $0-10$
b) $10-20$
c) $20-30$
d) $30-6060-100$

11- Which ones are at risk for HIV infection?

a) Health care workers

b) Having unprotected sexual intercourse and having multiple partners

c) Intravenous drug use and joint needle usage

d) Being in a relationship with an HIV (+) individual

e) Traveling to high risk areas or living in a high risk area

f) Being exposed to sexual violence

g) Tuberculosis disease

h) Unprepared medical interventions

\section{Appendix 1. Continued}

12- How much is the possibility of HIV transmission with a needle stick injury?
a) 0.3
b) 3
c) 30
d) 0
e) 100

13- Which route/routes is HIV transmitted? (you may choose more than one)
a) Thorough blood
b) Intravenous drug use
c) Sexual relations
d) Body fluids (sweat, tears)
e) Personal belongings (clothes, towels)
f) In air
g) Skin contacts (handshakes)
h) Domestic items (forks, knives)
i) Common use areas (pool, gym)
j) Toilets, sinks
k) Insect bites
l) From mother to infant during birth
m) Organ transplant 


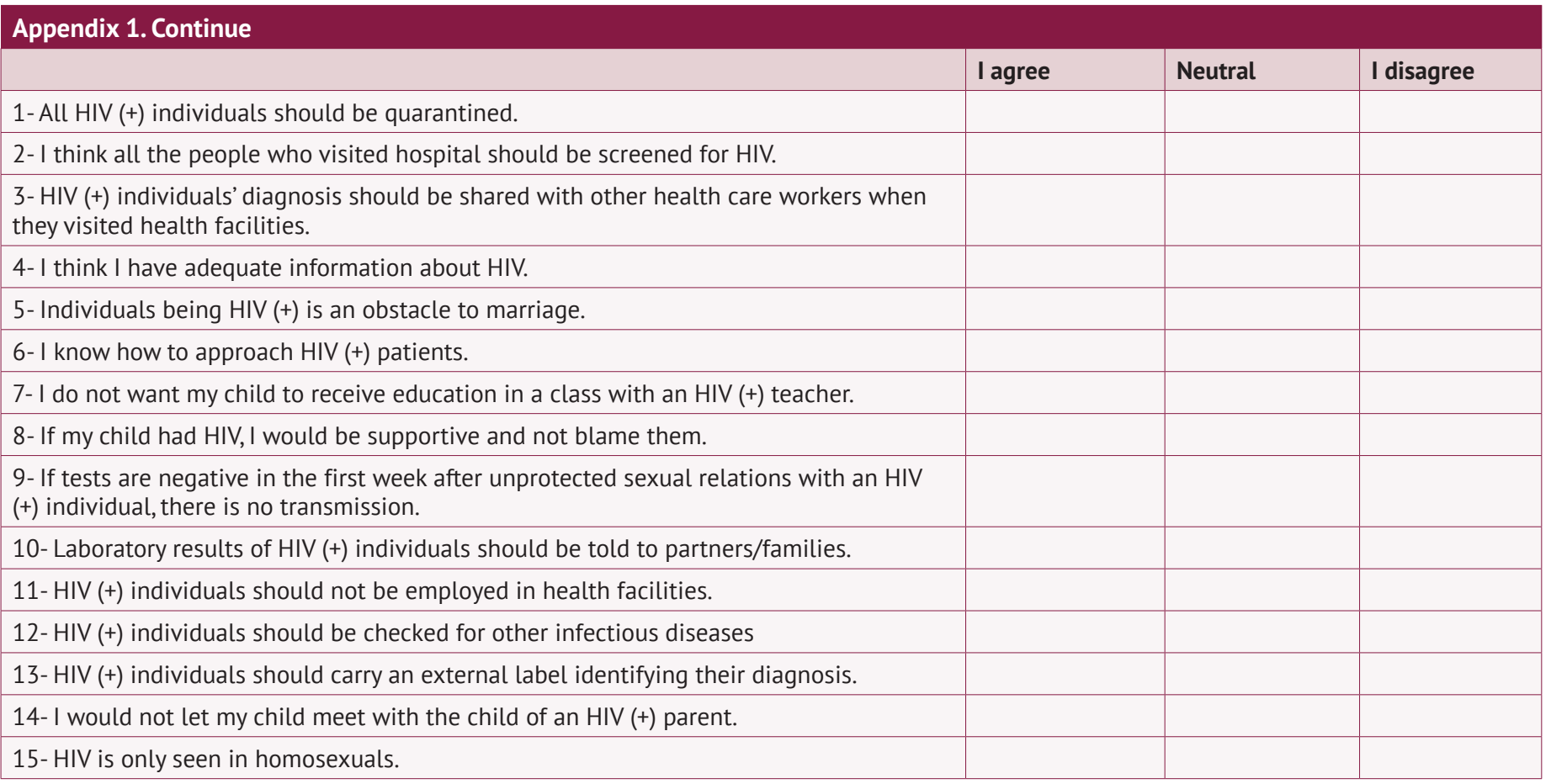

